\title{
Peningkatan Produktivitas Kelompok UKM Suvenir Desa Pematang Johar, Kabupaten Deli Serdang
}

\author{
Salam Irianto Nadeak*, Yusmar Ali, Komda Saharja, Faudunasoki Telaumbanua, Suhendra, Siti Aisyah \\ Politeknik Negeri Media Kreatif, Medan, Indonesia \\ Email: *salamirianto66@gmail.com
}

\begin{abstract}
Abstrak-Mitra kegiatan program Pengabdian ini adalah Kelompok / Komunitas UKM suvenir Pematang Johar yang berjumlah 20 orang anggota. Dari hasil diskusi dengan mitra UKM disepakati untuk menyelesaikan masalah: pengetahuan terkait kewirausahaan, keterampilan mencetak/menyablon, kreativitas pengolahan sablon yang memiliki daya jual, membangun berbagai ragam desain, rekayasa peranti digital, bagaimana mengerjakan jasa dan perdagangan system online. Berdasarkan kupasan diatas maka menangani kesulitan yang dihadapi Kelompok UKM suvenir Pematang Johar disepakati bersama akan perlunya memberikan pengetahuan dan motivasi kepada Kelompok UKM tentang pentingnya berwirausaha untuk masa depan. pelatihan keterampilan mencetak/menyablon. Memberikan pelatihan mengenai teknik produksi sablon kaos secara kompehensif. Fasilitasi alat yang dibutuhkan untuk pelatihan. kreativitas pengolahan sablon yang memiliki daya jual. membuat berbagai jenis desain dengan menggunakan aplikasi komputer. pemakaian tools digital. dan mengupayakan jasa dan perdagangan secara online dan menggunakan social media. Hasil Pengabdian menunjukkan peningkatan dalam hal: Pemahaman berwirausaha, pengetahuan teknik produksi, pengetahuan tools produksi, kualitas produksi, ketrampilan desain, Kesejahteraan Hidup, teknik pemasaran online, pengetahuan digital printing, ketrampilan digital printing
\end{abstract}

Kata Kunci: Produktivitas; Sablon; Pematang Johar; UKM; Digital Printing

\begin{abstract}
Partners for this Community Service program are the Pematang Johar souvenir SME Group/Community, which has 20 members. From the results of discussions with SME partners, it was agreed to solve problems: knowledge related to entrepreneurship, printing/screen printing skills, creativity in screen printing processing that has sales power, building various designs, engineering digital devices, how to do services and trading online systems. Based on the explanation above, in dealing with the difficulties faced by the Pematang Johar souvenir SME Group, it was mutually agreed on the need to provide knowledge and motivation to the SME Group about the importance of entrepreneurship for the future. printing/screen printing skills training. Provide training on t-shirt screen printing production techniques in a comprehensive manner. Facilitate the tools needed for training. screen printing processing creativity that has selling power. create various types of designs using computer applications. use of digital tools. and seeking services and commerce online and using social media. Service results show improvement in terms of: Entrepreneurial understanding, knowledge of production techniques, knowledge of production tools, production quality, design skills, Life Welfare, online marketing techniques, digital printing knowledge, digital printing skills.
\end{abstract}

Keywords: Productivity; Screen Printing; Pematang Johar; UKM; Digital Printing

\section{PENDAHULUAN}

UKM menjabat pucuk tombak dan penjamin perekonomian daerah karena keandalan UKM menerimakan fitrah terbesar dan berarti ambang Produk Domestik Bruto (PDB) inti ihwal ini perembesan kekuatan kriya. Menurut Sumber Kementerian Koperasi dan UKM periode 2013-2015 bahwa UKM masih berperan penerima mayoritas bagian dalam kawasan kontribusi yakni semenjak 54.114.821 perkara kontribusi hari 2013 menjabat 56.534.592 perkara kontribusi hadirat hari 2015. Sedangkan kawasan Usaha Besar semata-mata menyebar seputar 3.262.023 kekuatan kriya dekat periode 2015 (Amiruddin, 2018). Data fakta memperlihatkan perkiraan bidang usaha kecil mikro dan menengah (UMKM) menuju 99,98 \% terhadap kuantitas bidang jasa di Indonesia. Sementara perkiraan kekuatan kriya yang join menyebar 91,8 juta famili atau 97,3\% terhadap serata kekuatan kriya Indonesia (Idris, Iswandi; Hasibuan, Helviana; Efriza, Doni; Sari, Aditya, 2017).

Setiap UMKM rata-rata meresap 3-5 kekuatan kriya. Maka berkat adanya pengumpulan seputar 3 juta bidang sehingga kekuatan kriya yang masuk meningkat 15 juta orang. Pengangguran diharapkan menerjal turun 6,8\% sampai 5\% dengan perubahan UKM tersebut. Hal ini menggambarkan sokongan bagi UKM terhadap laju kemajuan ekonomi memegang sensasi cukup tinggi sebagaimana pemerataan ekonomi Indonesia karena memang berkedudukan cukup besar di kawasan ril (Idris, Iswandi; Hasibuan, Helviana; Efriza, Doni; Sari, Aditya, 2017)

UKM juga bisa berlaku efektif otoritas untuk menyurutkan taraf pengangguran yang terdapat di Indonesia. UKM di Indonesia mampu meresap berbagai personil kriya Indonesia yang masih belum memiliki kegiatan atau mengganggur. Selain itu, UKM akan berkontribusi cetak biru untuk mengintensifkan kompensasi negara maupun kompensasi zona Indonesia. UKM bisa menunggangi berbagai Sumber Daya Alam yang berpotensial di daerahnya yang belum diselesaikan secara jual beli sehigga UKM bisa berkontribusi dan sehat melakukan Sumber Daya Alam yang terdapat di lingkungan dimana UKM itu berada. Hal ini bisa berkontribusi strategi terhadap pertambahan kompensasi lingkungan maupun kompensasi zona Indonesia (Suhendar \& Suhardi, 2018). 
Desa Pematang Johar menjadikan bagian dari berasal 5 (lima) kampung yang terdapat di Kecamatan Labuhan Deli Kabupaten Deli Serdang. Provinsi Sumatra Utara. Mata profesi dasar publik Desa Pematang Johar cukup beragam, namun yang terbesar adalah ambang zona pertanahan gabah parak. Potensi pertanahan gabah tegal di Desa Pematang Johar sangat besar, sebesar ukuran tanah pertanian 1.750 Ha bisa membentuk rata-rata 7 Ton/Ha sekali tiba panen, tanah pertanian tersedia di dukuh I,II, III, IV, V, VI, VII, VIII,IX, X, XIII, XIV dan VX. Dengan lebarnya keandalan pertanahan yang dimiliki oleh Desa Pematang Johar ini Bupati Deli Serdang pertautan menerimakan penghargaan bercorak Penghargaan Adhikarya Pangan Nusantara Kategori Pembina Ketahanan Pangan. Di Desa Pematang Johar perkiraan hadir BUMDES yang bernama "Johar Mandiri Jaya", yang muncul tahun 2017 yang mula saham awalnya berasar pecah APBDes tahun 2017 sebanyak Rp. 20.000.000,pakai surah kontribusi Wifi (hotspot) kelak ditahun 2018 diberikan penghimpunan aktiva sebanyak Rp. 120.000.000,- pakai komplemen bidang tumpuan bercorak penyediaaan ATK, Foto Copy, Brillink, Batik parak dan peservis remunerasi elektrik online (Johar, 2019). Selain itu di desa Pematang Johar juga berkembang berbagai UKM UKM produk produk masyarakat yang bisa meningkatkan perekonomian masyarakat. Salah satunya adalah UKM yang bergerak dibidang suvenir/sablon.

Perkembangan usaha suvenir dan sablon di Desa Pematang Johar dan sekitarnya jika dibandingkan dengan Kota Medan memang agak kurang, karena SDM suvenir dan sablon yang memiliki kualitas bagus di kawasan ini belum banyak seperti di Kota Medan. Sebenarnya di Kota Medan dan sekitarnya terdapat cukup banyak pengusaha sablon kaos manual, namun kebanyakan memiliki mutu produk yang kurang berdaya saing. Kekuatan taring konvensional niaga ini adalah bertapak ambang talenta pelepasan kualitas sehati tambah ekspektasi konsumen.

Mitra kegiatan program Pengabdian ini adalah Kelompok / Komunitas UKM suvenir Pematang Johar yang terdiri dari 20 orang anggota putus sekolah yang memposisikan diri mereka untuk support wisata sawah yang ada di desa Pematang Juhar dengan membuat asesoris / cenderamata dan sablon. UKM suvenir Pematang Johar dirintis oleh Muhtadin dengan pembina Sudarman, jumlah anggota 20 orang, usaha ini dimulai dengan kegiatan membuat berbagai cinderamata dan asesoris. Dalam menjalankan usahanya peralatan yang digunakan sebagian besar masih manual. Pemasaran hanya dilakukan dilokasi wisata sawah dan manajemen sangat sederhana. Produk suvenir yang dihasilkan semua berasal dari limbah rumah tangga seperti lampu hias, tempat tissue, bingkai photo, fas bunga, gantungan kunci dan berbagai produk lainnya. Sedangkan untuk sablon dilakukan secara manual dan hasilnya cetak dikertas seperti undangan sertifikat, spanduk, namun untuk kaos sudah pernah dilakukan namun hasilnya tidak memuaskan karena kualitas rendah.

Mitra UKM Suvenir Pematang Johar didirikan tahun 2019 yang berlokasi di desa pematang johar seiiring dengan viralnya lokasi Wisata Sawah Bumbes Pematang Johar. Komunitas UKM ini terbentuk karena kesadaran bahwa antar anggota perlu mendukung Bumdes Wisata Sawah dan adanya komunikasi anggota untuk berbagi pengetahuan dan pengalaman, serta diharapkan bisa saling menjadi penolong di antara anggota. Tempat usaha masih menggunakan rumah, belum ada gallery pajangan, peralatan seperti mini compressor, mini grinder dan peralatan sablon masih belum dimiliki UKM.

Dari tala pengerjaan persepsi bagian adalah alat/dipan komidi gambar komposisi. menjelang mengerjakan teknik pemfileman komposisi sementara ini masih menunggangi cahaya surya yang berharap kehati-hatian dan kesaksamaan kala. Jika surya terik kala yang dibutuhkan berkitar 10-30 tempo jika mendung atau hampir soreh perian masa yang dibutuhkan 40-50 saat. Dari orientasi efisien pendayagunaan cahaya syamsu sangat direkomendasikan karena tidak berharap masa termin akan tetapi ketikan hendak gelap gulita teknik pemfileman formasi tidak bisa dilakukan karena teknik pemfileman memerlukan cahaya ultraviolet (Paserangi \& Jumawan, 2019). Selain berasal gerai filem, usaha finising juga berperan perkara sejawat. Selama ini perlengkapan finising yang digunakan sejawat adalah setrika. Untuk nilai risiko metode sablon ditentukan berpokok taktik finising, karena dawat yang digunakan mempunyai value yang berbeda-beda. Cetak sablon sehari hari umumnya final dikenal oleh publik namun semata-mata satu sisi point saja yang mengetahui, mengenal, dan menapakkan kaki pengetahuan ini. Cetak gambar ini menjadikan ragam pengetahuan bermanfaat yang tampak melintas liku-liku kehidupan dan sangat renggang warga menyelami kawasan ini menjadikan keluaran fase latihan khusus. Perkembangan cetak gambar yang kencang disebut screen printing sehaluan pakai sirkulasi zona fashion dan zona percetakan dewasa ini. Untuk berwirausaha cetak gambar ini mesti mempunyai pengetahuan, pengertian dan kepandaian teknis dan estetis (Mulyawati \& Pradita, 2018).

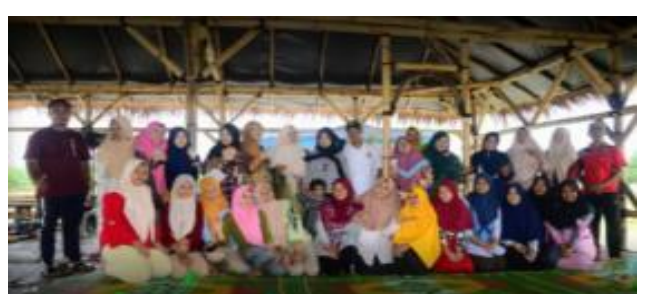

(a)

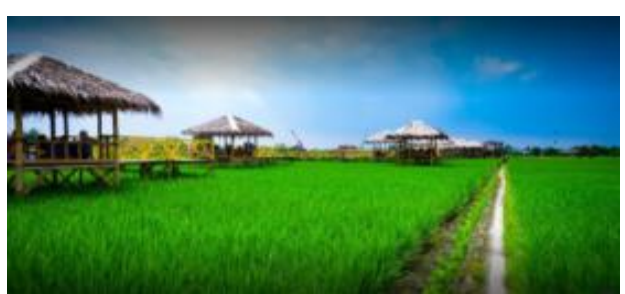

(b)

Gambar 1. a. Komunitas UKM suvenir Pematang Johar, b. Lokasi Wisata Sawah 


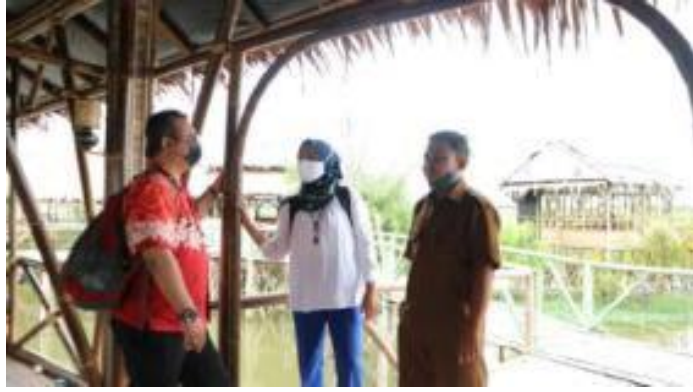

(c)

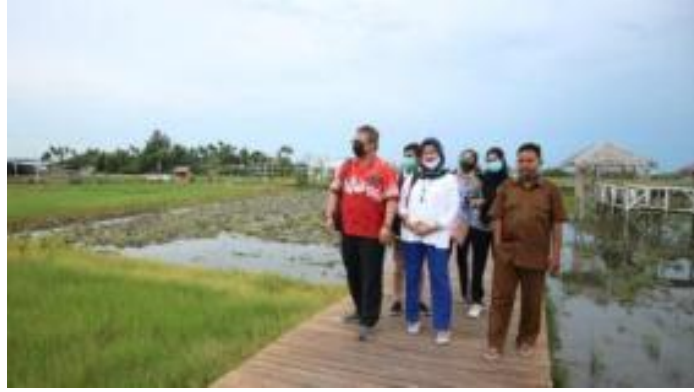

(d)

Gambar 1. c. Peninjauan lokasi mitra oleh tim abdimas Polimedia, d. Diskusi dengan mitra terkait masalah UKM

Padahal prospek usaha UKM suvenir ini sangat menjanjikan karena lokasi strategis di daerah wisata sawah Bumdes, namun semua pengelolaannya klasik dan produknya itu itu saja. Motivasi menjelang meluaskan andil yang sedang dirintis sangat tinggi, bagian ini tampak imaji setelah dilakukan permufakatan dan dialog bersama Bapak Muhtadin. Lokasi dan rekan sangat strategis bagi Politeknik Negeri Media Kreatif PSDKU Medan dalam hal promosi kampus maupun kolaborasi serta edukasi masyarakat sehingga layak diprioritaskan untuk didanai dalam skema Pengabdian Kepada Masyarakat Binaan (PKMB) Polimedia anggaran 2021.

Berdasarkan uaraian permasalahan mitra, maka solusi yang ditawarkan dalam memecahkan permasalahan mitra adalah sebagai berikut:

1. Permasalahan pemahaman mitra UKM berwirausaha rendah.

Untuk memecahkan permasalahan mitra ini ditawarkan solusi yaitu memberikan pengetahuan dan motivasi kepada Kelompok UKM tentang pentingnya berwirausaha untuk masa depan. Hal tersebut dilakukan dengan membuka wawasan tentang wirausaha di bidang sablon kaos beserta peluang prospektifnya

2. Permasalahan Pengetahuan mengenai teknik produksi masih kurang.

Maka solusi yang ditawarkan adalah dengan memberikan pelatihan keterampilan mencetak/menyablon. Memberikan pelatihan mengenai teknik produksi sablon kaos secara kompehensif Sehingga solusi ini nantinya akan menghasilkan Peningkatan kemampuan produksi dengan biaya yang minimal namun mampu menghasilkan produk yang berdaya saing tinggi.

3. Permasalahan peralatan sederhana.

solusi yang ditawarkan adalah dengan Fasilitasi alat yang dibutuhkan untuk pelatihan anggota komunitas UKM. Sehingga solusi ini nantinya komunitas UKM memahami penggunaan alat yang diberikan.

4. Permasalahan kualitas produksi rendah.

Solusi yang ditawarkan adalah adanya kreativitas pengolahan sablon yang memiliki daya jual. Sehingga solusi ini diharapkan munculnya inovasi dan kreasi dalam menciptakan produk.

5. Permasalahan desain kurang menarik

Solusi yang ditawarkan adalah membuat berbagai jenis desain dengan menggunakan aplikasi komputer. Solusi ini diberikan dengan melatih ketrampilan kelompok UKM dalam mendesain menggunakan aplikasi berbasis desain komputer seperti corel draw dan photoshop

6. Permasalahan pengelolaan masih sederhana

Solusi yang ditawarkan adalah penggunaan peralatan digital. Solusi ini diharapkan mitra memiliki pengetahuan dan pemahaman terkait digital printing

7. Permasalahan pemasaran kurang

Solusi yang ditawarkan adalah melakukan usaha dan pemasaran secara online dan menggunakan social media. Solusi diberikan agar mitra tidak hanya fokus menjual produk secara offline tapi sudah menggunakan aplikasi social media dan internet.

\section{METODE PELAKSANAAN}

Dalam pelaksanaan pengabdian ini, penulis melakukan dalam 5 tahapan, diantaranya:

Tahap 1. Tahap Persiapan

Tahap 2. Tahap Pelaksanaan Workshop

Tahap 3. Metode Pendekatan Workshop

Tahap 4. Partisipasi Mitra

Tahap 5. Evaluasi Kegiatan

Dari tahapan di atas, dapat dilihat tahapan tersebut pada gambar 2 berikut ini. 


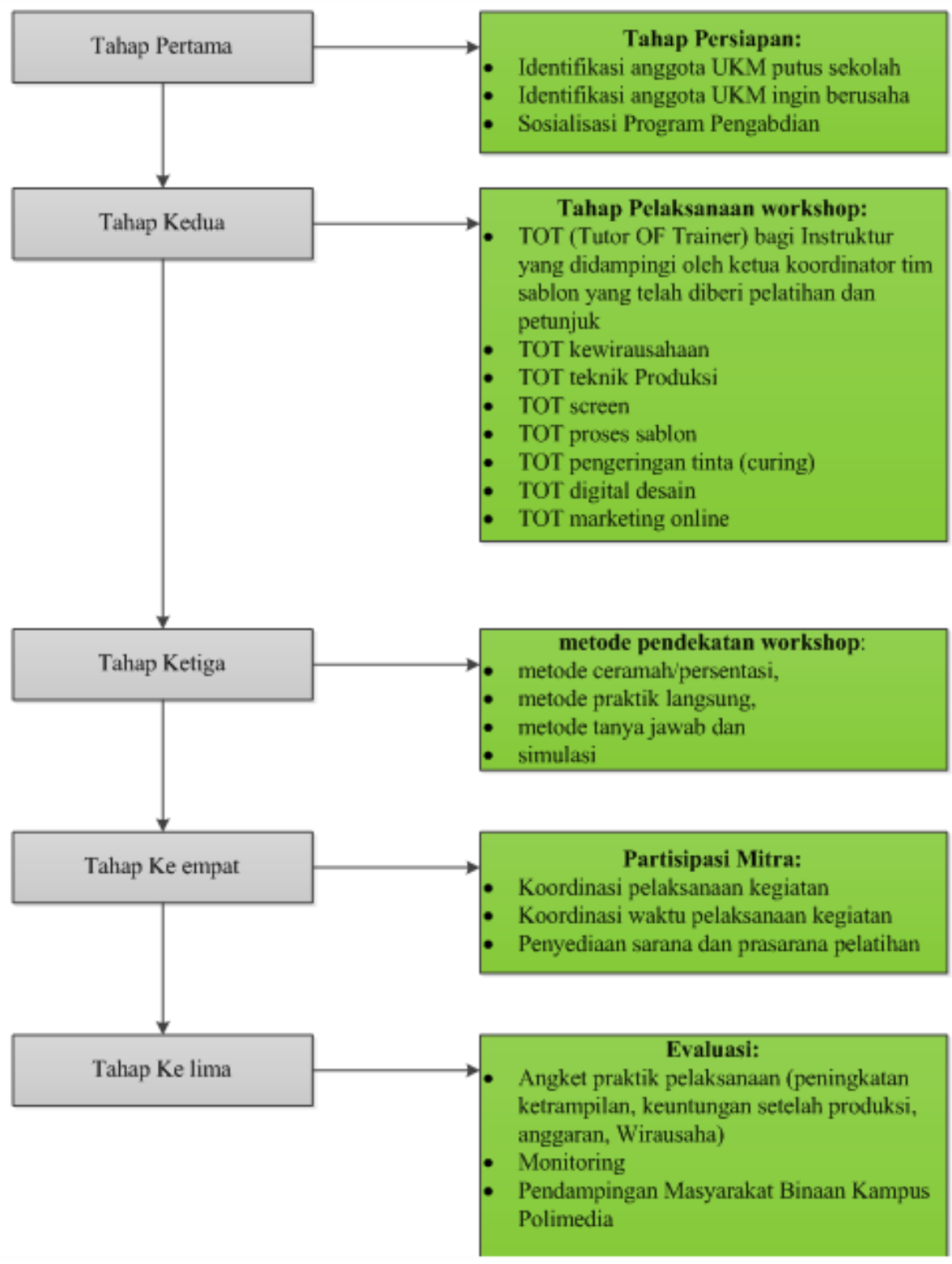

Gambar 2. Tahapan Pelaksanaan Pengabdian

\section{HASIL DAN PEMBAHASAN}

Pengabdian dalam kegiatan Pengabdian Kepada Masyarakat Binaan ini mencapai keberhasilan karena dukungan berbagai pihak yang terkait dan mau bekerjasama dengan baik, yaitu pihak mitra (sasaran). Keberhasilan kerjasama juga terjadi karena akar permasalahan diperoleh dari pihak mitra sendiri.

Pelaksanaan kegiatan dilakukan di Bulan Mei - Agustus 2021. Kegiatan dilaksanakan dalam bentuk pelatihan dan pendampingan dengan beberapa kali tatap muka dan daring .Pelaksanaan kegiatan dilakukan dilokasi Mitra yaitu Desa Pematang Johar, baik di Aula Desa Pematang Juhar maupun di BUMDES Wisata Sawah, dan juga melalui media conference Whatsapp dan Zoom.

Tahapan penyelesaian masalah mitra adalah:

TOT Kewirausahaan, TOT Teknik Produksi, TOT Screen, TOT proses Sablon, TOT proses Sablon, TOT Proses Pengeringan Tinta, TOT Digital desain, TOT Digital Printing, TOT Marketing online, Pelaksanaan worskhop serta inovasi produk.

TOT Kewirausahaan fokus eksplorasi Pengertian kewirausahaan, Ciri-ciri wirausaha yang berhasil, Pola Pikir Entrepreunership, Hambatan Persepsi saat memulai dan menjalankan Usaha, Kreatifitas Finansial Intrepreuner, Awali dari bisnis rumahan, Tips Jitu Memulai Wirausaha, Mencari modal berbisnis dan Motivasi Berwirausaha.

Kebutuhan akan kewirausahaan semakin meningkat dikarenakan munculnya permasalahan seperti: 


\section{Journal of Social Responsibility Projects by Higher Education Forum}

Vol 2, No 2, November 2021, Page 77-82

ISSN 2723-1674 (Media Online)

1. Semakin banyak pesaing yang mempunyai keunggulan

2. Ketidakpercayaan akan metode-metode tradisional dalam manajemen

3. Banyak SDM berpotensi hengkang dan lebih memilih menjadi wirausaha

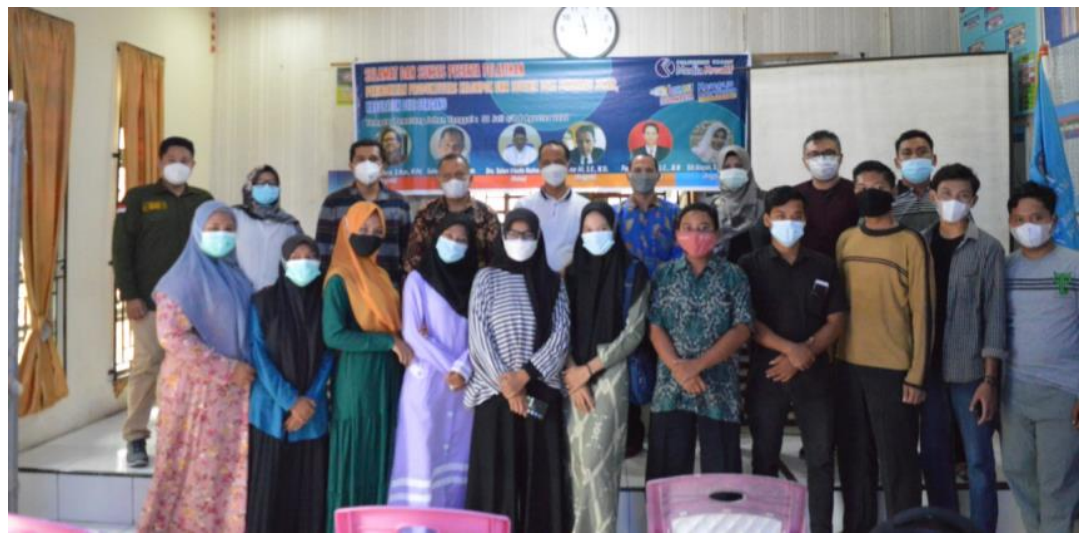

Gambar 3. Suasana pelatihan

Dalam TOT digital printing juga membahas Kelebihan Digital Printing :

1. Waktu Produksi Jauh Lebih Cepat

2. Bisa Mencetak / Print jumlah sesuai keinginan ( Print On Demand), tanpa harus ada Minimal Order, bahkan untuk mencetak dalam satuan.

3. Proses Produksi Mencetak lebih Ringkas, dan Hasil Cetak / Print bisa langsung kelihatan.

4. Tenaga Kerja yang lebih sedikit karena Proses Produksi yang lebih sedikit.

5. Proses Kerja yang tidak Rumit, sehingga mudah dilakukan meski oleh Pemula dalam Bisnis Digital Printing.

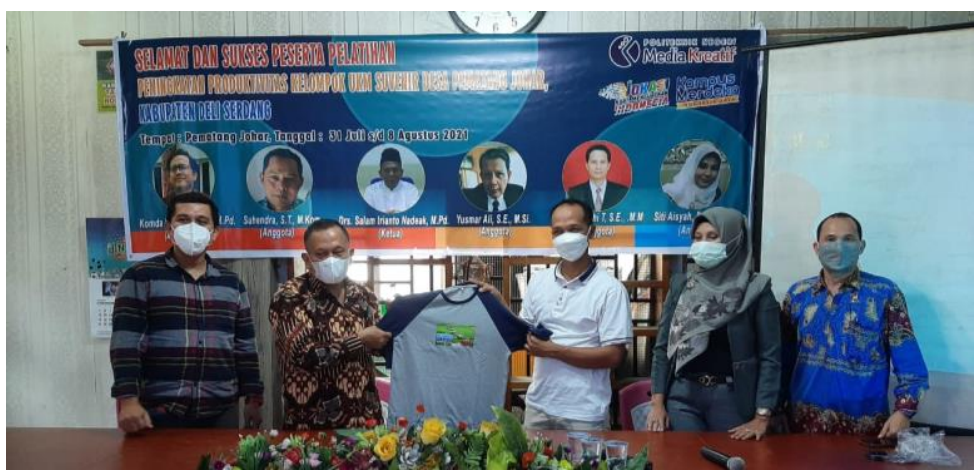

Gambar 4. Serah terima baju digital printing hasil pengabdian kepada mitra

TOT Marketing online fokus dalam memberikan informasi mengenai pemanfaatan pemasaran daring bagi dunia UKM, pengenalan mengenai media sosial yang bisa digunakan untuk iklan seperti Instagram dan Facebook serta Shopee. Kemudian memaparkan cara mendaftar akun di Facebook dan shofee, membuat halaman facebook, mendaftar akun instagram, mendaftar ke shopee serta mengenalkan bagaimana cara beriklan di kedua media sosial tersebut dan mengenalkan fitur-fitur yang dimiliki facebook dan instagram serta shopee Dampak dari Pengabdian masyarakat bagi mitra dapat dilihat pada gambar dibawah ini:

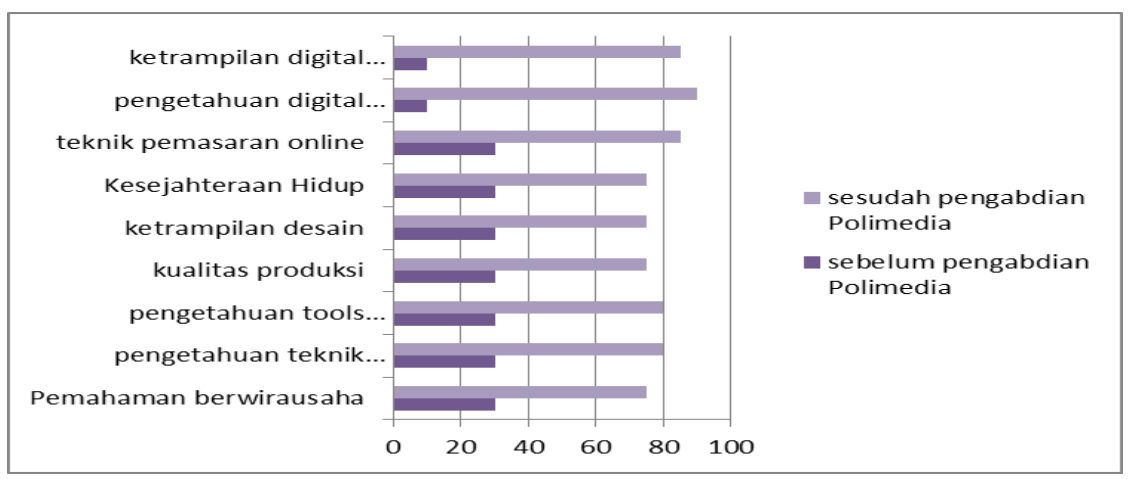

Gambar 5. Dampak kenaikan ketrampilan dan pengetahuan bagi mitra 
Dari gambar di atas menunjukkan perubahan signifikan dari Pelaksanaan Pengabdian Masyarakat Binaan Polimedia, antara lain meningkatkan Pemahaman berwirausaha mitra dari 30\% menjadi 75\%, dari data tercatat bahwa pengetahuan teknik produksi juga meningkat $80 \%$, pengetahuan tools produksi naik $80 \%$, kualitas produksi melesat 75\%, ketrampilan desain bertambah 75\%, Kesejahteraan Hidup mengalami peningkatan 75\%, teknik pemasaran online $85 \%$, pengetahuan digital printing meningkat $90 \%$ serta ketrampilan digital printing naik $85 \%$

\section{KESIMPULAN}

Training of Trainer (TOT) Kewirausahaan, TOT Teknik Produksi, TOT Screen, TOT proses Sablon, TOT proses Sablon, TOT Proses Pengeringan Tinta, TOT Digital desain, TOT Digital Printing, TOT Marketing online, worskhop serta inovasi produk memberikan manfaat yang cukup signifikan bagi mitra UKM Suvenir Pematang Johar.

\section{DAFTAR PUSTAKA}

Amiruddin, A. (2018). Pemberdayaan Usaha Kecil Menengah (UKM) Binaan Dinas Perdagangan Kota Surabaya Dalam Upaya Meningkatkan Kesejahteraan. Universitas Airlangga.

Idris, Iswandi; Hasibuan, Helviana; Efriza, Doni; Sari, Aditya, R. (2017). Ibm Peningkatan Produktivitas Kelompok Usaha Roti "Nenot-Nenot" Kelurahan Suka Ramai Medan. Jurnal Teknovasi: Jurnal Teknik Dan Inovasi, 4(1), 51-58.

Johar, D. P. (2019). Ekonomi Masyarakat.

Mulyawati, I., \& Pradita, M. (2018). Pelatihan Sablon bagi Karang Taruna dalam Menciptakan Peluang Bisnis. Jurnal SOLMA, 7(September), 299-308.

Paserangi, I., \& Jumawan, F. (2019). Program Kemitraan Masyarakat ( PKM ) Berbasis Teknologi Tepat Guna ( TTG ) Clothing di Makassar. Abdimas Toddopuli: Jurnal Pengabdian Pada Masyarakat, 1(1), 63-68.

Suhendar, D., \& Suhardi, D. (2018). Optimalisasi Pengelolaan Usaha Kecil Menengah (Ukm) Kerupuk Dorokdok Desa Cibingbin Kecamatan Cibingbin, Kabupaten Kuningan. Empowerment: Jurnal Pengabdian Masyarakat, 1(02), 45-52. https://doi.org/10.25134/empowerment.v1i02.1573 